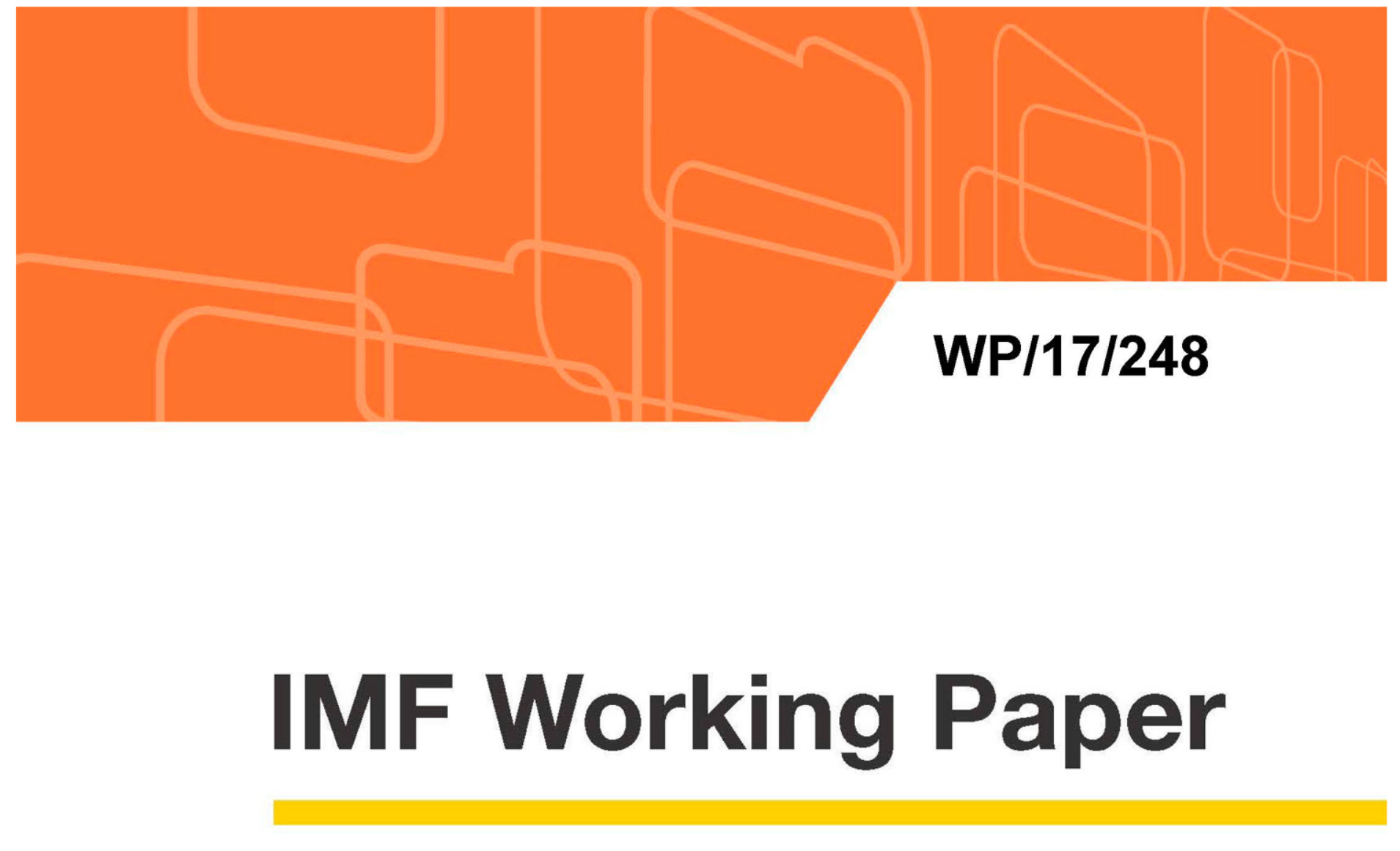

\title{
Assessing China's Residential Real Estate Market
}

by Ding Ding, Xiaoyu Huang, Tao Jin and W. Raphael Lam

IMF Working Papers describe research in progress by the author(s) and are published to elicit comments and to encourage debate. The views expressed in IMF Working Papers are those of the author(s) and do not necessarily represent the views of the IMF, its Executive Board, or IMF management. 


\section{WP/17/248}

\section{IMF Working Paper}

\section{Assessing China's Residential Real Estate Market}

by Ding Ding, Xiaoyu Huang, Tao Jin and W. Raphael Lam

IMF Working Papers describe research in progress by the author(s) and are published to elicit comments and to encourage debate. The views expressed in IMF Working Papers are those of the author(s) and do not necessarily represent the views of the IMF, its Executive Board, or IMF management.

I N T E R N A T I O N A L M O N 


\title{
IMF Working Paper
}

Asia and Pacific Department

\author{
Assessing China's Residential Real Estate Market \\ Prepared by Ding Ding, Xiaoyu Huang, Tao Jin and W. Raphael Lam
}

Authorized for distribution by James Daniel

November 2017

\section{IMF Working Papers describe research in progress by the author(s) and are published to elicit comments and to encourage debate. The views expressed in IMF Working Papers are those of the author(s) and do not necessarily represent the views of the IMF, its Executive Board, or IMF management.}

\begin{abstract}
China's real estate market rebounded sharply after a temporary slowdown in 2014-2015. This paper uses city-level data to estimate the range of house price overvaluation across city-tiers and assesses the main risks of a sharp housing market slowdown. If house prices rise further beyond "fundamental" levels and the bubble expands to smaller cities, it would increase the likelihood and costs of a sharp correction, which would weaken growth, undermine financial stability, reduce local government spending room, and spur capital outflows. Empirical analysis suggests that the increasing intensity of macroprudential policies tailored to local conditions is appropriate. The government should expand its toolkit to include additional macroprudential measures and push forward reforms to address the fundamental imbalances in the residential housing market.
\end{abstract}

JEL Classification Numbers: E43, E52, E58, F32, R31, C11, C32

Keywords: China real estate market, housing bubbles, macroprudential policy

Author's E-Mail Address: dding@,imf.org, huangxy.13@pbcsf.tsinghua.edu.cn, jint@pbcsf.tsinghua.edu.cn, wlam@,imf.org

\footnotetext{
${ }^{1}$ Ding Ding and W. Raphael Lam work for the International Monetary Fund. Xiaoyu Huang and Tao Jin work for the PBC School of Finance, Tsinghua University. We would like to thank James Daniel, Sonali JainChandra, Markus Rodlauer and participants at the IMF-People's Bank of China seminar for helpful comments, and Yuchen $\mathrm{Wu}, \mathrm{Xin} \mathrm{Xu}$, and Tlek Zeinullayev for excellent research assistance. The usual disclaimer applies.
} 


\section{Introduction}

After a temporary slowdown in 2014-2015 China's real estate market rebounded sharply in 2016. As signs of overheating emerged, the government turned to tighten real estate markets through a range of macroprudential and administrative measures. Many empirical studies point out that the house price surge is driven by fundamentals, while others consider the pickup of real estate activity is unsustainable (Fang and others 2015; Glaeser and others 2016; Shi 2017). This paper uses city-level real estate data to estimate the range of overvaluation of real estate markets across city-tiers, and assesses the main risks of a real estate slowdown and its impact on economic growth and financial stability.

Real estate has been a key engine of China's rapid growth in the past decades. Real estate investment grew rapidly from about 4 percent of GDP in 1997 to the peak of 15 percent of GDP in 2014, with residential investment accounting for over two thirds of the total real estate investment. Bank lending to the sector makes up 25 percent of total bank loans, about half of all new loans in 2016, and banks' increasing exposures to real estate, including through property developers and household mortgages, may

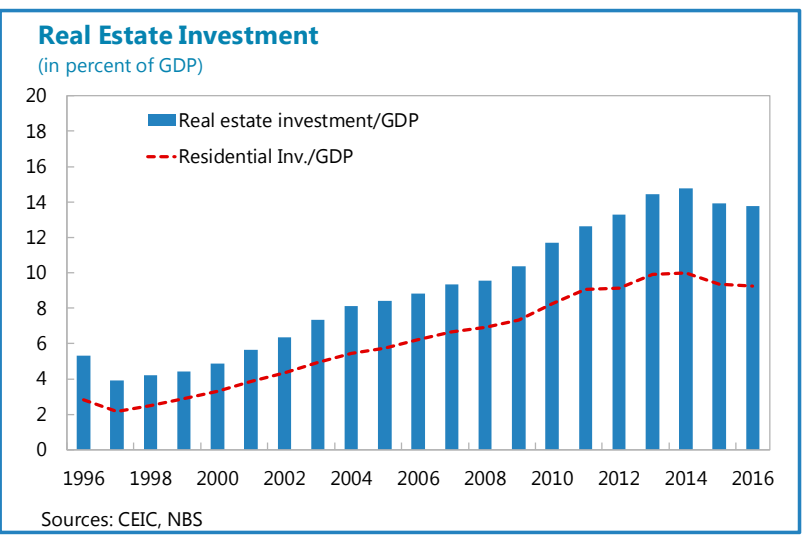
pose financial stability concerns. Real estate also has strong linkages to upstream and downstream industries (about a quarter of GDP is real-estate related). ${ }^{2}$ In addition, land sales are a key source of local public finance, accounting for about 30 percent of local government revenue in 2016, while general government net spending financed by land sales is about 9 percent of the headline revenue in 2016.There has been a rapid expansion of government subsidies on social housing, consisting of nearly 6 million apartment units in 2015-2017.

Real estate markets vary significantly in China because of its large economic size, economic and social diversity, and fragmented local government policies. The real estate cycles tend to be more pronounced in top-tier cities in terms of price volatility, but they account for a small fraction of real estate inventory and investment. ${ }^{3}$ Smaller cities constitute over half of residential real estate investment, but the price increase on average was much lower during 2013-16 (Table 1). ${ }^{4}$

Distortions render China's property market susceptible to both price misalignment and overbuilding. On the supply side, the market is distorted by local governments' control over land supply and their reliance on land sales to finance spending. On the demand side, the

\footnotetext{
${ }^{2}$ See Huang, $\mathrm{Wu}$, and $\mathrm{Du}$ (2008). Real estate has strong linkages with upstream industries such as cement and steel sectors and downstream industries such as autos, electronics and furniture.

${ }^{3}$ The real estate sector usually classifies Chinese cities into four tiers. Tier-1 consists of metropolitan cities including Beijing, Shanghai, Shenzhen, and Guangzhou. Tier-2 cities are usually provincial capitals, while Tiers-3 and 4 include smaller cities.

${ }^{4}$ The empirical study by Huang, Jin and Zhang (2016) reveals the periodical behavior of the housing price growth across 70 major Chinese cities.
} 
market is prone to overvaluation-housing is attractive as an investment instrument given a history of robust capital gains, high savings, low real deposit interest rates, a lack of alternative financial assets, as well as capital account restrictions.

The government has closely monitored real estate activity given its importance in the economy. Policies are highly decentralized, with local governments (often with local branches of the financial regulators) deciding land sale and infrastructure development, granting construction and sales permits to developers, and setting purchases restrictions. The central government and financial regulators can also affect the housing market through financing conditions and macro-prudential tools for mortgage lending.

\section{Housing Market Cycles and the Recent Developments}

After a temporary slowdown in 2014-2015 the real estate market rebounded sharply, following progressive policy easing by the government to stimulate the housing market and economic growth more broadly. Measures included loosening financing conditions through lower down-payment requirements and mortgage rates, housing-related tax cuts (both capital gains tax and stamp duties), and greater subsidies for social housing. ${ }^{5}$ Market sentiment was also motivated by official guidance to encourage household leverage. In June 2016, the State Council announced that "...the public and household sector can leverage up to some extent to help deleverage the corporate sector", a statement widely interpreted as easing signals for the housing market.

Real estate cycles. China has undergone frequent cycles in real estate markets - under a long-term upward trend - over the last decade. We identify easing and tightening periods, with peaks and troughs, on year-on-year growth of sales, prices, and inventory momentum (Table 2). ${ }^{6}$ For example, the three easing cycles between 2007 and 2016 had an average of about $1-1 \frac{1}{2}$ years in duration and all were affiliated with strong cumulative price and sales growth and an unwinding of inventory. On the other hand, tightening cycles were often associated with a fall in sales growth and a more modest growth in prices. The last cycle in 2015-16 saw a much stronger uptick for top-tier cities in prices (Table 2).

\footnotetext{
${ }^{5}$ In September 2015, the minimum down payment for first-home buyers was lowered from 30 per cent to 25 per cent and a further discretionary cut of 5 percentage points was authorized. Minimum down payments on second properties were reduced from 60-70 per cent to 30 per cent over the same period. Benchmark lending rates have been cut by around 165 basis points since late 2014, and the average effective mortgage rate has fallen by more relative to these benchmarks. Property transaction taxes were reduced and targeted subsidies were provided for certain types of home buyers.

${ }^{6}$ The timing and duration of the cycles are based on levels of peaks and troughs of $y / y$ growth in price, sales, and change of inventory ratios. Some judgment is applied as these series are not necessarily synchronized at the timing of different indicators.
} 
Prices. The price rally in the most recent cycle was concentrated in tier-1 cities, while nationwide prices increased more moderately (see Annex 1 on the house prices data). The nationwide 70-city new residential property price has risen by about 10 percent $\mathrm{y} / \mathrm{y}$ in nominal terms in June 2017 (8.5 percent in real terms, 13 percent weighted by population, and 16 percent weighted by sales value at city-tier levels), which represents a moderation in sequential

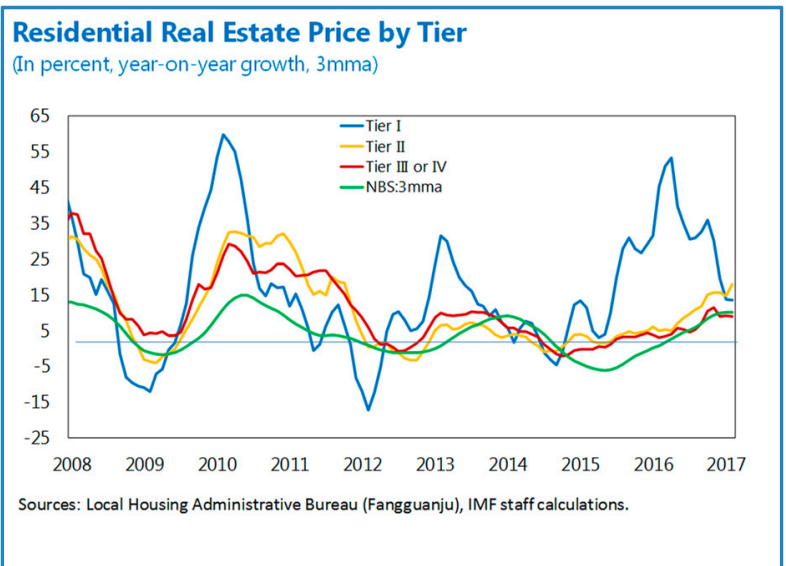
terms from the peak during the summer of 2016. Across city tiers, prices surged in tier-1 cities by as much as 55 percent y/y in early 2016 according to local housing bureau data, higher than the peak of the last easing cycle in 2013. Prices in tier-2 cities also increased by about nearly 20 percent $y / y$ at the peak, while the rise has been more modest in lower tier cities.

Property sales. Strong real estate sales were recorded across all city-tiers, rising by 22.5 percent $y / y$ in 2016 and 16 percent in the first half of 2017. In fact, the majority of the sales rebound - in terms of floor space and to a lesser extent in terms of value - has been in lower tier cities in this upturn, thanks to credit easing and government measures to unwind excess inventory. Surveys also indicated that almost half of the buyers who bought in the last 12 months brought forward their purchase decision in response to favorable market conditions and expectation of further tightening measures (Wright et al 2016). Total sales in this easing cycle have reached near 1.6 billion square meters since May 2015, well beyond the previous peak of 1.3 billion in 2012-13 (Table 2).

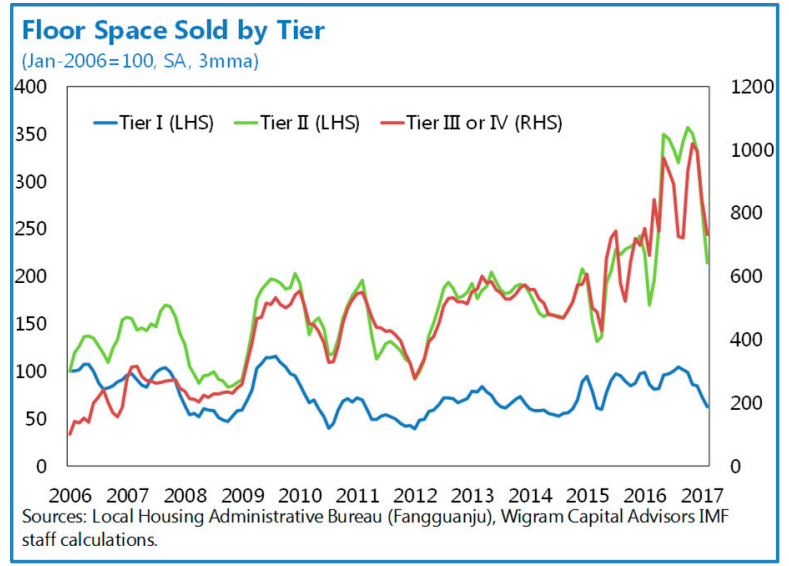

Real estate investment and housing starts. Real estate investment reversed the decelerating trend (with a trough of 1.2 percent y/y in December 2015), albeit much more mildly relative to previous upturns (Table 2). Real estate investment follows generally a six to nine-months lag after price and sales recover and therefore is expected to rise before moderating, if the recent moderation in prices takes hold. Overall, real estate investment currently stands at about 10 percent of GDP, below the historical peak level at 15 percent of GDP in 2014.

Inventory. Strong sales coupled with soft housing starts have led to a rapid destocking across all city-tiers, with a few city exceptions in the Northeast that continued to face significant oversupply. The nationwide housing inventory ratio (measured by unsold units to 
annualized sales) has declined sharply to about 18-20 months from 30 months at the peak in 2014, but the unsold volume in square meters remains higher than in previous cycles. Inventory levels varied significantly across city-tiers:

- $\quad$ Tier-1 cities had no excess inventory to start with in 2014 before sales surged. Supply conditions remain tight with unsold units persistently below a year of sales.

- $\quad$ Tier-2 cities have seen a notable decline of inventory ratios from its peak, with major ones (e.g., Nanjing, Hangzhou, and Xiamen) starting to face tight supply with limited new real estate completions.

- $\quad$ The large stock of inventory in tier-3 and 4 cities from previous overbuilding has gradually unwound, partly driven by supportive measures and the shifting focus of the government's social housing initiatives to buying existing properties from developers.

The inventory ratio has come down from its peak of $3 \frac{1}{2}-4$ years to now at about $2 \frac{1}{2}-3$ years as of the first half of 2017, which however was still higher than pre-2013 levels and the size of floor space unsold has remained high. For example, some cities in the northeast region continue to face high inventory levels. Overall, the recent round of property upturn differed somewhat from previous real estate cycles, with the investment rebound slower and more modest, and the price surge largely concentrated in tier- 1 and a few tier- 2 cities.
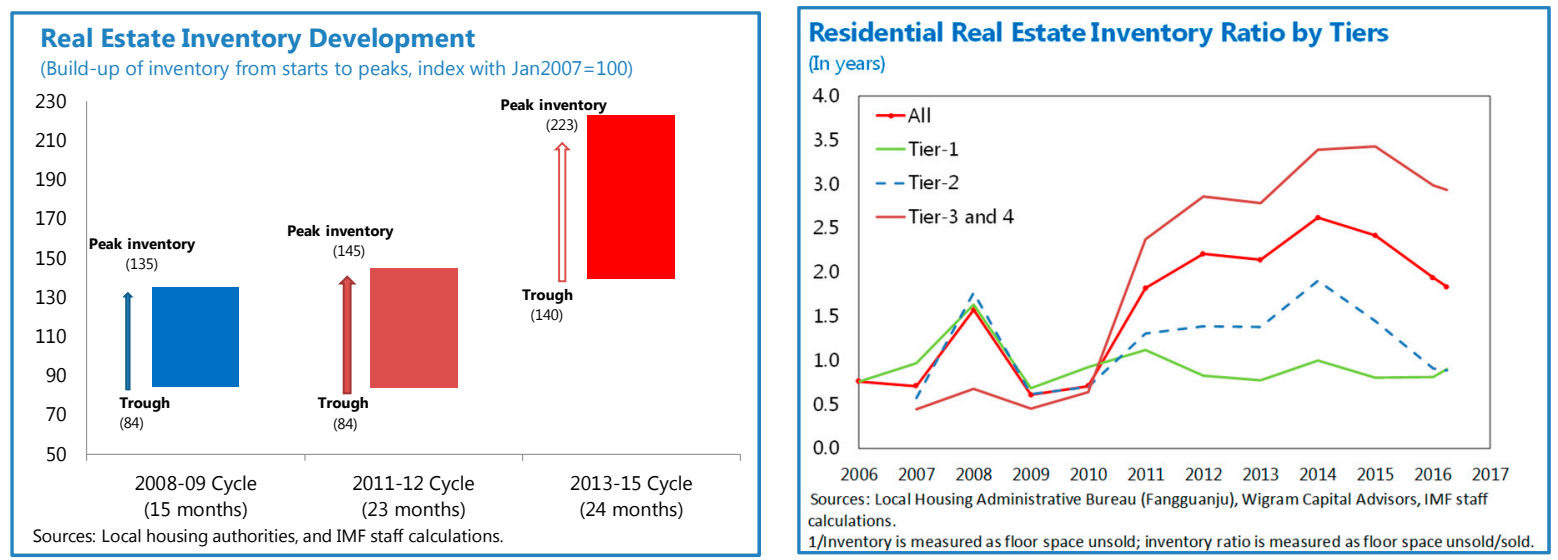

Mortgage lending. The strong rebound in the housing market was correlated strongly with the growth of mortgage credit, partly driven by easier financing conditions. Banks saw an unprecedented rise of the mortgage share in total new bank loans from 20-30 percent in 2013-2015 to nearly 50 percent in 2016, with the annual growth rate of mortgage loans doubling from 17 percent in 2014 to 35 percent y/y. Down payment ratios have remained high for new mortgages (40 percent of buyers of a first home have a down payment ratio of 25 percent or higher), but the average loan-to-value ratio, calculated as net new mortgage to property sales ratio, has increased from less than 15 percent in 2012 to 48 percent in 2016 , 
suggesting that buyers, particularly first-time home buyers, are using more leverage to purchase properties. $^{7}$

Household balance sheet. Households balance sheets have remained robust, though buffers are eroding. The rapid growth of mortgage borrowing has contributed to an increase of household debt from less than 20 percent of GDP in 2008 to 46 percent by the end of 2016 , with mortgages accounting for more than half of outstanding household debt. Although this ratio is still far below the average OECD level of 102 percent of GDP, it is already higher than in some other large emerging economies and economies in Asia. ${ }^{8}$

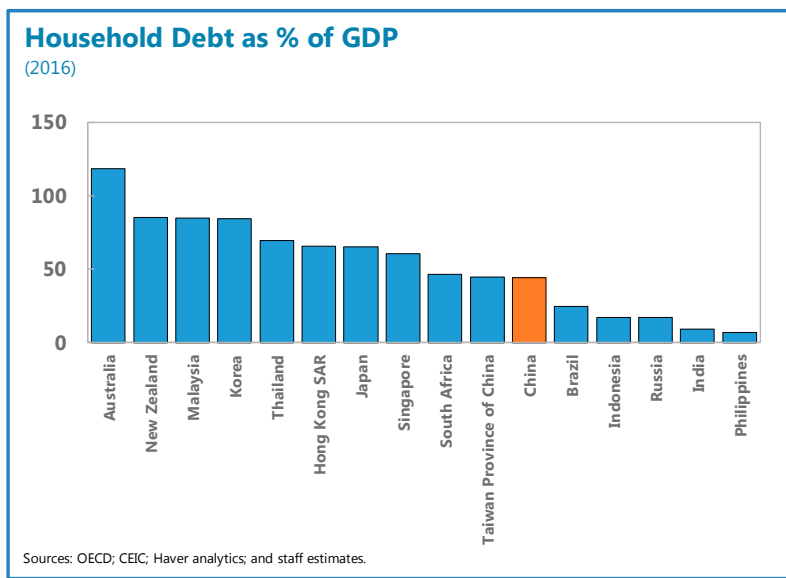

Land supply. Limited land supply particularly in top-tier cities also contributed to the strong rebound of real estate prices (Wu, Gyourko and Deng 2016). Land sales volume (measured in terms of floor space) by local governments to residential developers has contracted by half since 2014 , despite the recent recovery of land sales value this year.

Emerging signs of speculation. Emerging signs of speculation have appeared in the top-tier cities. Market surveys suggest that about 18 percent of residential home sales in 2016 were related to investment demand (buyers of second homes), doubling the average level of 6-10 percent between 2012-2015. This would imply about 10-15 percent of new mortgage borrowing are from buyers of second homes, considering their higher mortgage rates and down payment ratios. ${ }^{9}$ Household mortgage leverage could be even higher if we take into down payment loans provided by real estate developers or via shadow banking loans, for which no data are available. There is also anecdotal evidence of speculation/excess exuberance, for example, the divorce rate in Shanghai jumped to bypass expected purchase restrictions, while in Shenzhen there were reports of buyers borrowing from real estate agents to finance the down payment for second homes.

Recent tightening measures. As signs of overheating emerged, the government took a range of measures, differentiated across cities (Table 3). Key measures include:

\footnotetext{
${ }^{7}$ Banks' mortgage rates are usually determined at a discount or premium of $0-15$ percent below or above the benchmark lending rate set by the central bank. Banks have the discretion to adjust the discount or premium based on market conditions. Most mortgage contracts have fixed rates for about 10-20 years based on the benchmark lending rates.

${ }^{8}$ Granular data on household debt are not available across household groups (income and age) or regions to provide finer assessment on the soundness household balance sheets. Other alternative indicators such as household debt to income ratio and service capacity are relatively scare without full time series for crosscountry comparison.

${ }^{9}$ Our estimates are based on down payment ratios and real estate sales from 355 bank lending surveys.
} 
- Tighter down-payment requirements. Several tier-1 and 2 cities have tightened down payment requirements for home purchases to at least 30 percent and even higher for second homes, often at 50-70 percent.

- Home purchase restrictions. Local governments have reintroduced or reinforced purchases restrictions for non-local residents and for second or third homes in the tier-1 and 2 markets, largely targeted to speculative demand.

- Financing restrictions. Financial regulators have increasingly restricted the use of shadow funds and informal lending to finance property developers or the down payment of marginal buyers. They also have tightened significantly bond issuance for property developers. At the same time, the government provided window guidance to banks to limit mortgage lending and enforce better the down payment and collateral requirements.

- Land supply. A number of local governments also tightened land bidding requirements to prevent developers from excessive bidding by raising deposit requirements and hoarding of undeveloped land. Some cities (e.g., Tianjin) also considered applying greater flexibility on land use rights in a targeted manner, for example, by relaxing restrictions on land density and by converting land of commercial use to residential use.

- Others. The central government also signaled policy intentions to anchor public expectations. For example, recent remarks by officials have warned of a real estate market bubble and indicated the government's priority on reining in asset price risks.

The tightening measures have had an impact on real estate markets, as evidenced by the moderation in price rises especially in sequential month-on-month basis, new mortgage loans, and real estate sales. Our empirical analysis also indicates that changes to down payment requirements have been effective in dampening price cycles (see section IV).

\section{Risks of a Housing Market Correction and the Potential Impact}

\section{A. Risks of a sharp correction in the housing market}

The main near-term risks of the real estate market are the housing bubble in top-tier cities expanding to smaller cities, increasing the likelihood and costs of a sharp correction in house prices. This in turn would weaken growth through slowing real estate investment and private consumption, and pressure financial stability via developers' funding and mortgages of financial institutions. The standard metrics does indicate some overvaluation in the residential market, especially in the large cities.

- Price trend. Overall nationwide house prices deviate only some 5 percent from their long-term trend (based on HP filtering) and the deviation is broadly similar to previous cycles. However, the deviation for large tier-1 cities is much greater at about 10-15 
percent. Previous cycles that saw this level of deviation from trend usually ended with a slowdown in real estate activity.
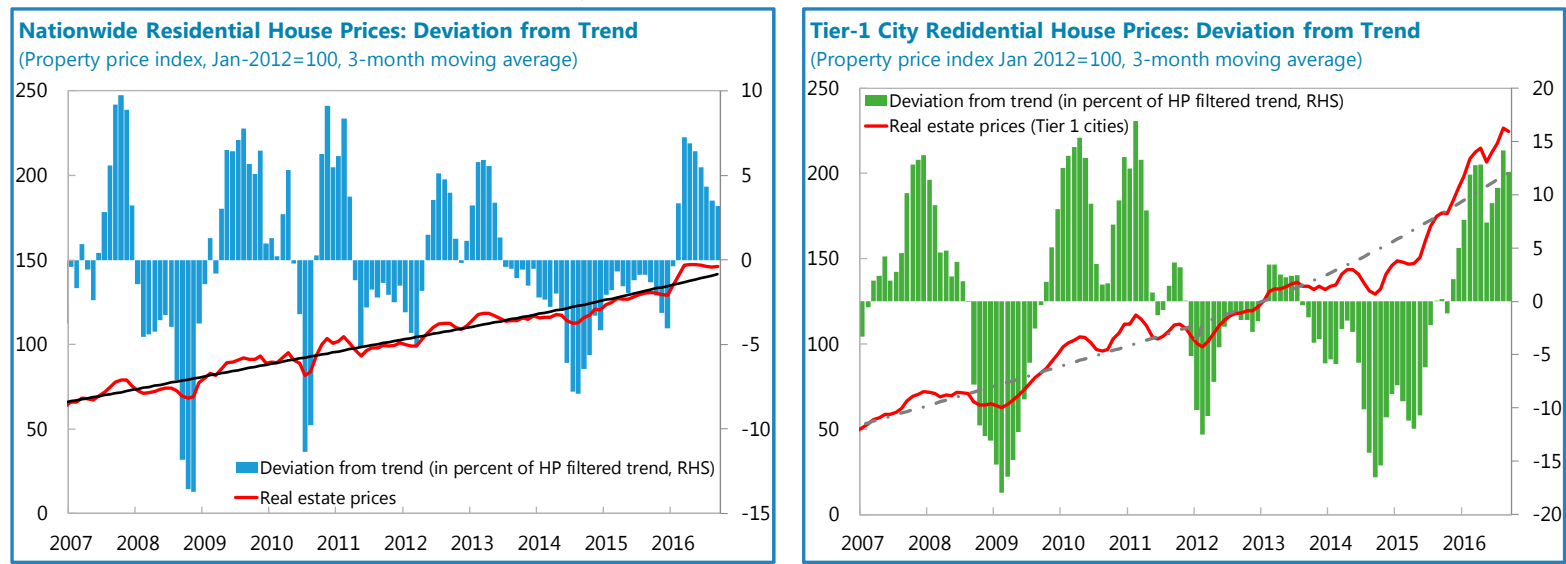

- Affordability. Affordability in terms of price-to-income ratio has deteriorated over the past year, but mainly in the large cities, where house prices stood at over 15-25 times of city-level disposable household income, on par with international major cities. The national average price-to-income ratios have been declining steadily since 2010 and is about half of that in the large cities. ${ }^{10}$ At the same time, rental cost also rose to over onethird of household disposable income but remained low relative to house prices (rental yields for tier 1 cities have been low at less than 3 percent).

- Debt service to income. Household debt servicing capacity improved due to lower mortgage rates and rising household income. Successive cuts to benchmark rates since 2014 and the revival of discounted rates on mortgages (10 percent lower than the benchmark rate) have reduced monthly mortgage burden. The effective mortgage rate was 4.49 percent (and 5.4 percent for second-home buyers) in March 2017, about 160 basis points lower than in early 2014 . However, aggregate nationwide measures may have masked the deterioration of debt-service for some new buyers in top-tier cities.

Prices for top-tier cities are increasingly frothy with the sharp rise in prices and deteriorating affordability. Outside of tier-1 and a few tier-2 cities, price deviates little from long-term trend. The sharp gains in tier-1 prices have been partly driven by fundamentals (e.g., limited land supply, expectation of strong income growth, and ongoing urbanization), though the extent of their contribution to price gains is uncertain. Other recent studies also suggest that the current price level could be consistent with future income growth and limited land supply (Glaeser et al 2016; Shi 2017).

\section{B. Impact on economic activities}

\footnotetext{
${ }^{10}$ National average income may not be the best indicators given the unusually wide distribution of labor and household income in China (see IMF 2017).
} 
Growth impact. Although nationwide prices do not seem overvalued as indicated by trend analyses, the recent surges in prices of major cities and mortgage borrowing are unsustainable. Various distortions in China's real estate market also make it sensitive to policy changes. There is a risk that aggressive attempts to cool house prices could trigger a sharp correction and wider adverse effects. A correction of house prices by 10-15 percent from currently 5 percent above the long-term trend to about 5 to 10 percent below trend (roughly the magnitude in previous cycles) would affect the macro-economy and financial stability through the following channels:

- Real estate investment. A sharp price decline would generate a downward spiral on real estate investment, which could put the current above-trend level to the previous trough level, possibly slowing fixed asset investment by about 11 percentage points or about 6 percent in growth of real estate gross fixed capital formation in the national accounts. As residential real estate contributes roughly $9 \frac{1}{2}$ percent of GDP, estimates suggest that the deceleration of real estate investment growth alone would reduce GDP growth by 0.6 percentage points. Upstream sectors, such as steel, cement, and construction machinery, would be more

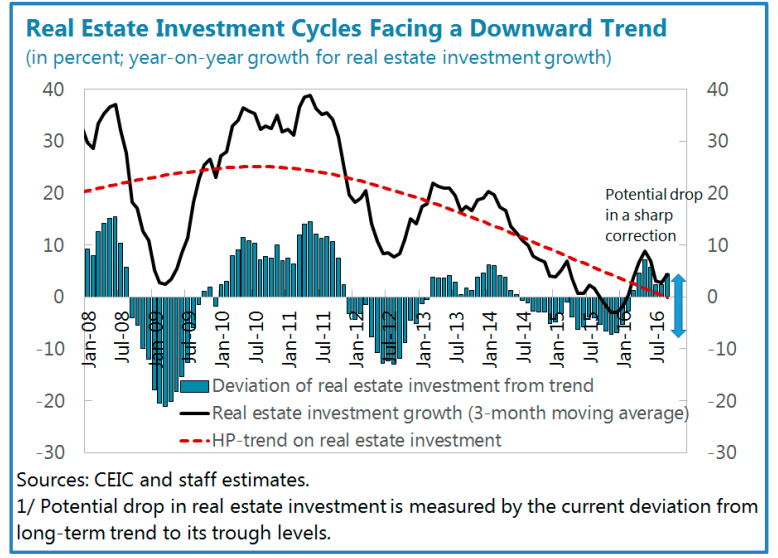
affected.

- Private consumption. Changes in house prices could affect household consumption through two main channels: a direct wealth effect and a collateral effect (Flood and Morin 2008). Given that mortgage refinancing and home equity loans are few in China, the wealth effect is the most important channel through which a price correction would impact consumption, particularly on downstream industries such as autos and electronic appliances. Based on cross country estimates of long run propensity to consume out of housing wealth (e.g., Flood and Morin 2008 and IMF 2008), a correction of house prices by 10-15 percent is likely subtract $0.1-0.2$ percentage points from growth in 201718. ${ }^{11}$ Combined with the investment

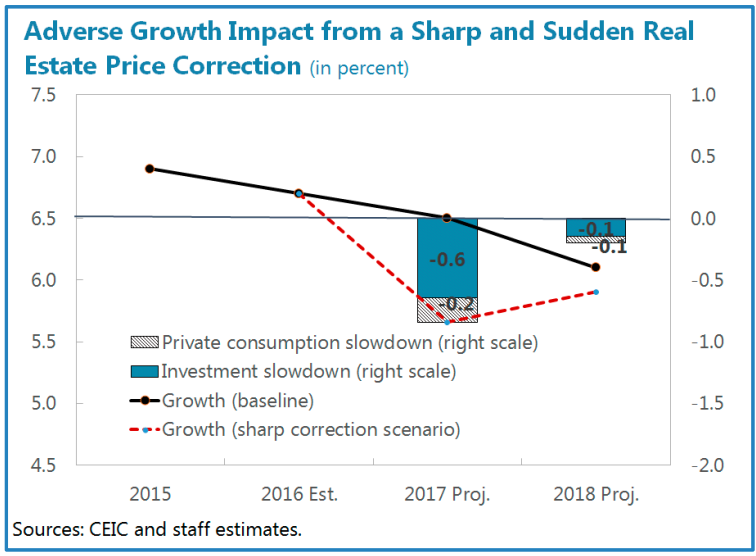

11 The IMF's Global Macro-Financial Model (Vitek 2015), a structural macro-econometric framework, estimated that a 10 percent reduction of house prices in China driven by a housing risk premium shock can (continued...) 
impact, this would reduce growth by some 0.9 percentage points. At the same time, a sharp decline in house prices could dampen confidence in other asset prices.

Fiscal impact. An additional channel through which a price correction could affect the macro-economy is local government financing. Local governments have relied heavily on land sales revenue to finance their spending. A sudden sharp correction in prices would weaken local public finances significantly. Even if local governments manage to maintain prices by restricting land supply, tighter government spending would have knock-on effects on growth (IMF 2015).

Capital outflows. Against the weakening growth trend, the property market has stood out as an asset class that offers continuous positive returns to investors, especially given the recent equity market correction and moderation in bond prices. A sharp weakening of the property market may trigger capital outflows as households switch to foreign assets, adding to depreciation pressures. The pressure could intensify if compounded with weakening growth momentum and a strengthening of the dollar as the result of Fed tightening.

\section{Impact on financial stability}

A sharp correction in the housing market may also pose risks to financial stability through the following channels:

- Banking sector. The direct exposure of the banking sector to the real estate market is moderate; household mortgages and loans to property developers represent a total of 15 percent of bank assets. Bank loans to corporates that are collateralized by property or land make up another 10 percent of banks' total assets. China's high savings rate and the relatively large minimum down payment requirements for mortgages mean that households in the aggregate are not highly leveraged, and the possibility of repossession and liquidation is low. But the buffers have eroded for the following reasons.

- Mortgage delinquency. Housing credit has increased sharply relative to the value of property sales, suggesting that buyers, especially marginal ones, are using more leverage to purchase property. ${ }^{12}$ On the other hand, the mortgage default rate has been low in China, possibly reflecting the fact that all household mortgages are recourse loans (Fang at el 2015).

- Linkages with nonbank finance. Property developers often raise funds outside the banking sector, but the banks are ultimately intermediating much of this lending and so are also exposed to this risk indirectly (discussed below).

\footnotetext{
generate a peak output loss of 0.63 percent, considered in isolation. (This estimated peak output loss ranges from 0.40 to 1.05 percent across economies.)

12 Data on the distribution of mortgage loans by household income and creditworthiness are not available.
} 
- Collateral devaluation. A sharp market correction may also result in revaluation of land and properties that many commercial lending uses as collateral.

- Concentration risks. Property sales in the top five provinces (Guangdong, Jiangsu, Zhejiang, Shandong and Shanghai) accounted for 44 percent of the national total, indicating possible concentration risk of banks' loan books.

- Capital outflows could put banks and bank-sponsored WMPs under liquidity pressure. The maturity transformation currently performed by the system could unravel, resulting in fire sales of assets, a rise of counterparty risk, and corporate bankruptcies.

- Shadow banking sector. In the event of a sharp market correction, shadow bank products that are exposed to the property market may face redemption as they cannot meet the expected returns for investors. Default rates would rise for borrowers that are dependent on shadow bank products as a source of funding as they come under liquidity/cash flow pressures. Liquidity pressure could also cascade down the intermediation ladder, reaching banks and other nonbanks, as well as nonfinancial borrowers. Banks will also have reputational losses-more specifically, banks would need to "buy" off balance sheet assets (of deteriorating quality) from shadow products to keep redeeming investors' claims. The recent upswing in household credit has been accompanied by reports of less creditworthy borrowers entering the housing market by obtaining credit through informal channels (such as peer-to-peer lending) to finance down payments. This raises both the risk of loan defaults and the potential size of any financial losses in the event that prices fall significantly.

- Real estate developers. Given the large stock of unsold properties especially in lowertire cities, any slowing in demand from current levels would pose potential risks for property developers.

- Smaller developers are particularly leveraged - they often fund land purchases using borrowed funds from shadow banks with the land as collateral—and do not have the alternative funding sources that some of the top developers can access (e.g., offshore borrowing and funding from parent companies). A sensitivity analysis by the Deutsche Bank (2016) indicates that a 10 percent decline in housing sales would result in an increase in debt-to-EBITDA ratio of the lowest quartile developers by 14 percentage points to 74 percent, while the top quartile developers will only see an increase of 2 percentage points. Smaller, local and unlisted banks are particularly exposed to the weak real estate developers via both bank loans and shadow funding.

- Large real estate developers would face significant refinancing pressure starting from 2018. Onshore and offshore bond maturing would increase from $\$ 5$ billion in 2017 to $\$ 10$ billion in 2018 (and $\$ 30$ billion by 2020). RMB depreciation would add to the cost of refinancing. 
Given these potential channels, a sharp market correction would likely lead to an increase in impaired loans and deterioration in profitability and capitalization of financial institutions. The impact through the mortgage channel is likely to be limited given still low household leverage. The highly leveraged small real estate developers, as well as small city-level banks that are exposed to the weak developers, are likely to be the weakest link in the short run.

\section{Other impact}

Social impact. Housing is the largest component of household wealth (about 60 percent). Along with underdeveloped social housing and the limited role of redistributive fiscal policies, the boom and bust in real estate could also have wider growth consequences that affect disproportionately low-income groups, including job losses in the low-skill construction sector and delinquency on debt service for marginal young buyers, which would intensify already-large income inequality and dampen the rebalancing progress.

Feedback loop. A strong housing market raises real estate collateral, which allows lending to grow, and boosts the overall economy, in turn boosting demand for housing. This feedback loop works in reverse during housing busts. A sharp decline in valuation and household and corporate borrowing would have knock-on effects on the real economy, which would exacerbate asset quality problems and amplify the impact of the initial shock. Banks and other intermediaries would be simultaneously hit by credit and market losses. China has also never experienced a significant decline in house prices over the long term, so there are "unknown unknowns" of how such a scenario would unfold. That said, the government still has much control over the real estate markets and the financial system, and will likely take measures to stabilize if needed (as it did in 2015).

\section{Policy Implications}

From a long-run perspective, continued urbanization and increase in household real incomes should provide support for sustained robust growth in China's property market. However, the recent excessive increase in house prices in major cities and the growing likelihood and costs of a significant correction warrant measures to deflate the real estate market smoothly, while containing risky mortgage lending. Indeed, the policies adopted so far by the authorities are broadly appropriate. They work mainly by introducing macro-prudential measures, which usually work more effectively ex-ante, and mitigating speculative demand via increasing the cost of purchase. Empirical studies also show that the government's housing market policies as a whole have been effective in damping price increases (Wang and Sun 2013).

\section{A. The effectiveness of existing macroprudential policies}

Given the significant divergence in China's housing markets, macro-prudential policies tailored to local conditions should continue to be the first line of defense, although they should be carefully calibrated to address potential leakages in light of the large shadow banking sector and to address the disproportionate adverse effects on younger and poorer households. The literature in general supports the effectiveness of macro-prudential policies 
(such as LTV limits) in building resilience to financial cycles (for an overview see Claessens 2014), though the evidence is stronger for reducing loan growth and improving debtservicing capacity, than curbing house price growth (Jacome and Mitra 2015).

In China, housing-related macro-prudential policies mainly consist of minimum down payments (LTV requirements) for first and second homes. ${ }^{13}$ The differentiated LTV limits by borrowers (first-time home buyers versus investors) and by regions are appropriate as they can be targeted at the riskier segments of the markets. Our empirical analysis confirmed that changes to down payment requirements for second homes have been effective in containing house price cycles, and indeed local governments tend to adjust these requirements in response to changing market conditions.

We first conduct a panel regression using the methodology in Igan and Loungani (2012). The basic model is specified as follows.

$$
\begin{gathered}
\Delta h p_{i, t}=\alpha+\beta_{i}+\beta_{1} A_{i, t-1}+\beta_{2} \Delta Y P C_{i, t}+\beta_{3} \Delta W A P_{i, t}+\beta_{4} \Delta C_{i, t}+\beta_{5} \Delta L T V_{i, t-1} \\
+\beta_{6} \Delta L S_{i, t-1}+\beta_{7} \Delta L G_{i, t}+\beta_{8} \Delta M R_{i, t}+\gamma Y+\varepsilon_{i, t}
\end{gathered}
$$

where $\Delta h p_{i, t}$ is the change in the real residential house prices in city $i$ over the last year, $A_{i, t-1}$ is the affordability level of housing in the previous year measured by the log of the ratio of house prices to income per capita, $\triangle Y P C_{i, t}$ is the change in real income per capita, $\triangle W A P_{i, t}$ is the change in working-age population aged between 18-64, $\Delta C_{i, t}$ is the change in bank credit to the private sector, $\Delta L T V_{i, t}$ is the change in loan to value ratio (down payment requirement for second homes) in the last period, ${ }^{14} \Delta L S_{i, t}$ is the change in land supply per capita in the last period, $\Delta L G_{i, t}$ is the change in local government fiscal deficit, $\Delta M R_{i, t}$ is the change in local mortgage rates, and $Y$ is a vector of macroeconomic variables including stock prices, exchange rate, interest rate and a dummy variable for house price downturns. We also included dummy variables for city-tiers (tier-1 and 2) and interact them with the loan to value ratios and land supplies.

Our sample included the annual data for 70 cities for which the National Bureau of Statistics reports the monthly house prices. For variables that are not available at the city level, namely, bank credit to the private sector and local government fiscal deficit, we use provincial level data as proxies. City-level data on the minimum down payment requirement for second homes indicate a loosening of the policy across city tiers in 2014-15 and a tightening in tier-1 and 2 cities last year.

\footnotetext{
13 The other frequently used tools include the reserve requirement ratio (RRR) and the different mortgage interest rates for first and second homes. Although they can affect housing market through the credit channel, they are generally viewed as a monetary policy instruments.

14 The loan to value ratios range from 20-35 percent for first home buyers across cities and provinces (more common for top-tier cities) and have varied moderately by about $+/-3-5$ percentage points over real estate cycles, subject to a minimum threshold of 20 percent.
} 


\begin{tabular}{|c|c|c|c|}
\hline \multicolumn{4}{|c|}{$\begin{array}{l}\text { Average Changes in Minimum Down Payment Requirements for Second } \\
\qquad \text { Homes }\end{array}$} \\
\hline & Tier-1 & Tier-2 & Tier- 3 and 4 \\
\hline 2005 & 0.050 & 0.010 & 0.000 \\
\hline 2006 & 0.050 & 0.090 & 0.100 \\
\hline 2007 & 0.100 & 0.100 & 0.100 \\
\hline 2008 & -0.200 & -0.200 & -0.200 \\
\hline 2009 & 0.000 & 0.000 & 0.000 \\
\hline 2010 & 0.300 & 0.300 & 0.300 \\
\hline 2011 & 0.100 & 0.100 & 0.100 \\
\hline 2012 & 0.000 & 0.000 & 0.000 \\
\hline 2013 & 0.075 & 0.029 & 0.000 \\
\hline 2014 & -0.175 & -0.156 & -0.150 \\
\hline 2015 & -0.150 & -0.123 & -0.100 \\
\hline 2016 & 0.200 & 0.025 & -0.048 \\
\hline ce & & & \\
\hline
\end{tabular}

Our regression results show significant impact of changes to down payment requirements on house prices, especially in tier-1 cities (Table 4). A tightening of down payment requirement by 10 percentage point in tier- 1 cities corresponds to a decline in real residential house prices by 3.5-4.5 percent, other things being equal. Increasing land supply per capita is also found to have a negative impact on house price increases.

In another exercise, we conduct a logit regression for the tightening and loosening of down payment requirements. As the dependent variable, the down payment ratio $L T V$, has three values: $0,1,2$ ( $0=$ loosening, $1=$ unchanged and $2=$ tightening). We use the multinomial logistic regression which is an extension of the standard logit regression. ${ }^{15}$ The basic model is specified as follows.

We set $L T V_{i, t}=1$ as the reference, i.e. the down payment ratio stays the same. For $m=0,2$,

$$
\begin{aligned}
\ln \frac{P\left(L T V_{i, t}=\right.}{P\left(L T V_{i, t}=\right.} & 1) \\
& =\alpha_{m}+\beta_{i m}+\beta_{1 m} \Delta h p_{i, t}+\beta_{2 m} F T_{i} * \Delta h p_{i, t}+\beta_{3 m} S T_{i} * \Delta h p_{i, t} \\
& +\beta_{4 m} \Delta \text { inventory }{ }_{i, t}+\beta_{5 m} F T_{i} * \Delta \text { inventory } y_{i, t}+\beta_{6 m} S T_{i} * \Delta \text { inventory }_{i, t} \\
& +\beta_{7 m} \Delta C_{i, t-1}+\beta_{8 m} \Delta M R_{i, t}+\gamma_{m} Y_{t}
\end{aligned}
$$

The coefficients in each equation ( $m=0$ or 2 ) represent the change in the likelihood $L T V=m$ as opposed to the case when down payment requirement stays the same. $\Delta h p_{i, t}$ is the $\mathrm{y} / \mathrm{y}$ change

\footnotetext{
${ }^{15}$ In the panel regression, we included lagged variables to control for endogeneity. The results indicate that the current level of $\triangle L T V$ does not significantly affect the current level of house prices. Therefore, we can rule out the simultaneous causality by using the current value of house price as a regressor in the logit regression.
} 
in the real residential house prices in city $I ; \Delta$ inventory $y_{i, t}$ the local housing inventory ratio, measured by unsold floor space units to annualized sales in city i in period t; $\Delta C_{i, t}$ the change in bank credit to the private sector; $\Delta M R_{i, t}$ the change in local mortgage rates; and $Y_{t}$ a vector of macroeconomic variables including stock prices, exchange rate, inter-bank offered rate of three month and a dummy variable for house price downturns. We also include dummy variables of city-tiers ( $F T_{i}$ for tier-1 cities and $S T_{i}$ for tier-2 cities) to interact with inventory variable and housing price variable.

Our regression results show significant impact of house prices on the adjustment of down payment requirements (Table 5). When house prices go up, there is a higher probability of tightening the down payment policy as opposed to the reference case, especially for tier-2 cities. Down payment requirements also respond significantly to the change of inventory ratios. When inventory ratio rises, local governments tend to loosen down payment requirements. Increasing local credit aggregates and mortgage rates are also found to have a positive impact on the likelihood of raising the down payment ratios as opposed to the reference case.

\section{B. Expanding the macroprudential toolbox}

Changes in the LTV limits can be pro-cyclical and result in higher credit losses in the future by allowing borrowers to borrow more during boom cycles. In this regard, the government should consider expanding the macro-prudential policy toolkit to include measures that have proven effective in containing housing market risks in other countries. Combining different tools can help lessen the shortcomings of any single tool and enable policymakers to use several transmission channels at the same time, thereby promoting effectiveness of policy responses (IMF 2014).

In particular, the government should make more active use of the DSTI (debt servicing to income) caps. DSTI requirements can restrict the size of debt service payments to a fixed share of household income, thereby ensuring affordability. They can also enhance the effectiveness of LTV limits in addressing excessive credit growth by restricting the use of unsecured loans to attain the minimum down payment. The $2004 \mathrm{CBRC}$ guidelines required a borrower's monthly mortgage payment to income ratio to be less than 50 percent and monthly total debt payment to income ratio to be less than 55 percent. These caps should be adjusted to the international norm of 30-50 percent and extended to other types of household loans including loans from non-bank financial institutions. The calibration of these caps should account carefully for the potential downsides that tend to affect younger and poorer households more adversely. Stress testing of household debt servicing capacity to interest rate and income shocks can also be used to gauge the potential risks in adverse scenarios.

The government should also consider sectoral capital requirements through risk weights or loan given default (LGD) floors on banks' exposure to the real estate sector. These requirements can be tightened during market booms to increase the cost of funding for property developers and build additional buffers (He et al 2016). On the other hand, although capital requirements are generally less distortionary as they work through the price of credit, they are often less effective in constraining excessive credit growth than tools such as LTV 
and DSTI caps, and may lead to arbitrage where loans are provided by domestic nonbanks and off-balance sheet vehicles. They may also be less effective on China's large real estate developers whose reliance on bank funding is limited.

To make better use of macro-prudential policies, the government also need step up efforts in collecting and processing information beyond aggregate credit and house prices. A wide range of indicators on borrowers, speculative activities and other qualitative indicators on risk taking should be analyzed and supported by judgment on the extent of systemic risk. Examples include the growth rate and distribution of mortgage loans by LTV ratios and borrowers' debt servicing capacity, cross-sectional differences in NPLs on loans with specific characteristics, share of banks' and nonbanks' loans to the real estate sector and to households, and qualitative indicators on financial sector risk-taking such as supervisory evaluations.

\section{Administrative and fiscal measures}

The government should reduce the reliance on administrative measures such as home purchase restrictions and funding restrictions over the medium term. Although they tend to be effective in suppressing demand in the short run, these measures can have an excessively abrupt impact, resulting in more distortions and circumvention compared to market-based or macro-prudential measures. Moreover, home purchase restrictions tend to affect disproportionately new migrants, thus undermining the efforts in urbanization.

While taxes on housing transactions and capital gains are effective instruments to dampen housing speculation, the government should also introduce recurrent property taxes gradually (but decisively) by overcoming the remaining hurdles on registration of properties and legislation procedures. The benefits are two-fold. First, cross country evidence points to the dampening impact of property taxes on house price volatility (Andrews 2010). Second, the introduction of recurrent property taxes can provide revenue sources for local governments to finance local public services and avoid excessive dependence on (volatile) land sales, which in turn would dampen the adverse effects of boom bust cycles in real estate. A (partial) decoupling of the house prices and local government financing is also likely to change households' expectation that the housing market is "too important to fail". Overall fiscal policy should support ongoing rebalancing efforts while gradually reducing the "augmented" deficit to its debt stabilizing level (IMF 2017).

\section{Structural policies}

More focus on increasing real estate supply at a pace commensurate with that of demand, especially in higher tier cities where incomes and productivity growth is highest, is welcome. Increasing land supply and building higher-density housing in major cities can attract migrants and facilitate a smooth transition in the housing market. ${ }^{16}$ This can be

\footnotetext{
${ }^{16}$ Population density in Chinese cities is typically much lower than major American metropolitan areas. For example, the first tier cities have population density varying from 1,000 to 2,000 people per square kilometer in
}

(continued...) 
complemented with reforms on social security and household registration (hukou) to give migrants from the rural area the full access to public services. Also, reducing China's very high level of domestic savings and gradually opening up the capital account in a wellsequenced and phased manner appropriately in tandem with other reforms would help reduce the propensity for asset price inflation/boom-bust cycles. In that context, greater exchange rate flexibility and a stronger monetary policy framework are essential.

More fundamentally, China should move away from the practice of setting annual growth targets that has fostered an undesirable focus on short-term, low-quality stimulus measures. The government has had the tendency of boosting infrastructure spending, real estate activity and credit during economic downturns to meet growth targets, creating the expectation that housing is an aggregate demand instrument. This expectation can reinforce the role of housing as an asset class and amplify the boom bust cycles. If the importance of growth targets were to diminish, dynamics in the real estate market would be more aligned to fundamental demand and supply conditions, which would allow the prudential policies to play the major role in guarding against macro-financial risks.

2010, whereas the top 100 American MSAs (metropolitan statistical area) all have density above 4,000 people per square kilometer (Glaeser et al 2016). 


\begin{tabular}{|c|c|c|c|c|c|c|}
\hline \multicolumn{7}{|c|}{$\begin{array}{l}\text { Table 1. Tier-1 Cities Catch the Most Attention but Account for a Small } \\
\text { Share of Real Estate Markets }\end{array}$} \\
\hline \multirow[b]{2}{*}{ (in percent of total) } & \multicolumn{3}{|c|}{2016} & \multicolumn{3}{|c|}{2013} \\
\hline & Tier 1 & Tier 2 & $\begin{array}{l}\text { Tiers } 3 \\
\text { and } 4\end{array}$ & Tier 1 & Tier 2 & $\begin{array}{l}\text { Tiers } 3 \\
\text { and } 4\end{array}$ \\
\hline Residential property sales (floor space) & 7 & 55 & 38 & 9 & 53 & 38 \\
\hline Residential property sales (value) & 21 & 54 & 26 & 29 & 52 & 20 \\
\hline Inventory (floor space of unsold units) & 10 & 54 & 36 & 8 & 63 & 29 \\
\hline Real estate investment & 8 & 33 & 59 & 7 & 31 & 62 \\
\hline
\end{tabular}




\begin{tabular}{|c|c|c|c|c|c|c|}
\hline \multicolumn{7}{|c|}{ Table 2. Real Estate Cycles during 2007-16 } \\
\hline Dates 1/ & $\begin{array}{l}\text { Jun } 2007- \\
\text { Feb } 2009\end{array}$ & $\begin{array}{l}\text { Mar } 2009- \\
\text { Jun } 2010\end{array}$ & $\begin{array}{l}\text { Jan } 2011 \text { - } \\
\text { Mar } 2012\end{array}$ & $\begin{array}{l}\text { Apr } 2012- \\
\text { Sep } 2013\end{array}$ & $\begin{array}{l}\text { Oct } 2013- \\
\text { Apr } 2015\end{array}$ & $\begin{array}{l}\text { May } 2015 \text { - } \\
\text { Aug } 2016\end{array}$ \\
\hline Real estate cycles & Tightening & Easing & Tightening & Easing & Tightening & Easing \\
\hline Peak & - & Apr-10 & - & Mar-13 & - & Apr-16 \\
\hline Trough & Jan-09 & - & Mar-12 & - & Mar-15 & - \\
\hline Duration (in months) & 19 & 9 & 13 & 18 & 16 & 15 \\
\hline \multicolumn{7}{|c|}{ A. Cumulative change between peaks and troughs } \\
\hline \multicolumn{7}{|l|}{ 1. Real estate prices (in percent) } \\
\hline $\begin{array}{l}\text { National Bureau of Statistics } \\
\text { (nationwide } 70 \text { cities) }\end{array}$ & 10 & 6 & 2 & 6 & -2 & 5 \\
\hline Local Housing Bureaus & 21 & 23 & 6 & 16 & 10 & 20 \\
\hline of which: Tier 1 cities & 9 & 45 & -12 & 32 & 12 & 50 \\
\hline of which: Tier 2 cities & 18 & 21 & 4 & 10 & 6 & 18 \\
\hline of which: Tier 3 or 4 cities & 30 & 21 & 10 & 17 & 16 & 12 \\
\hline \multicolumn{7}{|c|}{ 2. Property sale volume (in percent; floor space sold) } \\
\hline National Bureau of Statistics & 11 & 215 & -26 & 119 & -23 & 43 \\
\hline Local Housing Bureaus & -37 & 40 & -45 & 60 & -13 & 51 \\
\hline of which: Tier 1 cities & -36 & 19 & -33 & 33 & 11 & 36 \\
\hline of which: Tier 2 cities & -40 & 42 & -47 & 65 & -19 & 66 \\
\hline of which: Tier 3 or 4 cities & -4 & 39 & -44 & 56 & -8 & 11 \\
\hline \multicolumn{7}{|l|}{ 3. Inventory: floor space unsold (in percent) } \\
\hline Local Housing Bureaus & 43 & -30 & 52 & 0 & 49 & -19 \\
\hline of which: Tier 1 cities & 33 & -31 & 21 & -27 & 48 & -17 \\
\hline of which: Tier 2 cities & 53 & -31 & 63 & 9 & 38 & -25 \\
\hline of which: Tier 3 or 4 cities & 42 & 7 & 62 & -3 & 75 & -10 \\
\hline \multicolumn{7}{|l|}{ Inventory to sales ratio (in months) } \\
\hline Local Housing Bureaus & 15 & -11 & 20 & -13 & 10 & -11 \\
\hline Mortgage rates (in percent) & - & 0.0 & 1.1 & -0.5 & -0.8 & -1.2 \\
\hline \multicolumn{7}{|c|}{ B. Average growth during the cycles (in percent) } \\
\hline $\begin{array}{l}\text { Real estate fixed asset investment } \\
\text { growth (in percent } \mathrm{y} / \mathrm{y} \text { ) }\end{array}$ & 28 & 15 & 31 & 15 & 12 & 2 \\
\hline \multicolumn{7}{|l|}{ C. Deviation from HP-filtered trend } \\
\hline 1. Real estate prices (at peaks / troughs) & -14 & 8 & -5 & 6 & -8 & 7 \\
\hline $\begin{array}{l}\text { 2. Real estate fixed asset investment } \\
\text { (average across the cycle) }\end{array}$ & -5 & 7 & -6 & 2 & -4 & 3 \\
\hline \multicolumn{7}{|c|}{$\begin{array}{l}\text { Sources: NBS, Local Housing Bureaus, and staff estimates. } \\
1 \text { / The timing of the real estate cycles is based on data on sales, prices, and inventory on a 3-month moving } \\
\text { average basis. Judgement was applied to determining the timing of the cycles because the peaks and troughs of } \\
\text { growth insales and prices are not necessarily synchronized. }\end{array}$} \\
\hline
\end{tabular}




\section{Table 3. Recent Tightening Measures Have Contributed to the Cooling of Real Estate Markets}

\begin{tabular}{|c|c|c|c|c|}
\hline Date & Measures & Nationwide & $\begin{array}{l}\text { Tier } 1 \\
\text { Cities }\end{array}$ & $\begin{array}{l}\text { Tier } \\
\text { Citie }\end{array}$ \\
\hline & Home purchase restrictions & & & \\
\hline Mar-16 & $\begin{array}{l}\text {-Top tier cities required nonresidents to have a minimum of 3-5 years of social security } \\
\text { contributions to be eiligible for real estate purchases. }\end{array}$ & & $\sqrt{ }$ & \\
\hline Aug-16 & -Two tier-2 cities (Suzhou and Xiamen) reinstated purchase restrictions. & & & $\sqrt{ }$ \\
\hline Oct-16 & $\begin{array}{l}\text {-14 cities tightened home purchase requirements, including stricter criteria for nonlocal } \\
\text { buyers and setting the maxium number of homes a person can buy. }\end{array}$ & & $\sqrt{ }$ & $\sqrt{ }$ \\
\hline Nov-16 & - Tier 2 cities restricted nonlocals to buy second homes if they have properties in Tier 1 cities. & & & $\sqrt{ }$ \\
\hline \multirow[t]{2}{*}{ Nov-16 } & - 20 Tier 1 and 2 cities were on the watch list for real estate prices by the government. & & $\sqrt{2}$ & $\sqrt{ }$ \\
\hline & Down payment requirements & & & \\
\hline Mar-16 & $\begin{array}{l}\text { Tier } 1 \text { cities (Shanghai and Shenzhen) raised the down-payment ratio to } 40-50 \text { percent for } \\
\text { second homes. }\end{array}$ & & $\sqrt{ }$ & \\
\hline Jun-16 & $\begin{array}{l}\text {-Tier } 2 \text { city Hefei increased down-payment requirement for } 40-60 \text { percent for second and } \\
\text { third homes and restricted the use of housing provident fund for mortgages. }\end{array}$ & & & $\sqrt{ }$ \\
\hline Aug-16 & Several cities started to raise the down payment requirement. & & & $\sqrt{ }$ \\
\hline \multirow[t]{2}{*}{ Oct-16 } & $\begin{array}{l}\text {-Fifteen cities increased the down payment requirement, for example, to } 70 \text { percent for } \\
\text { second home purchase in Tier } 1 \text { cities, or tighten the use of housing provident funds. }\end{array}$ & & $\sqrt{ }$ & $\sqrt{ }$ \\
\hline & Financing restrictions & & & \\
\hline Mar-16 & $\begin{array}{l}\text { Financial regulator prohibited the lending by peer-to-peer (P2P) platforms and real estate } \\
\text { agents for down payment of buyers. }\end{array}$ & $\sqrt{ }$ & & \\
\hline Jul-16 & $\begin{array}{l}\text { CSRC prohibited the financing of real estate developers in excessive land bidding or bank loan } \\
\text { repayments. }\end{array}$ & $\sqrt{ }$ & & \\
\hline Oct-16 & PBC provided window guidance to 25 local banks on their mortgage lending. & & $v$ & \\
\hline Oct-16 & $\begin{array}{l}\text { ·Financial regulators (CBRC, CSRC, PBC) restricted developers' funding via entrusted loans and } \\
\text { brokers' asset management programs. }\end{array}$ & $\sqrt{ }$ & & \\
\hline Oct-16 & -Bond issuance threshold was raised for real estate developers. & $\sqrt{ }$ & & \\
\hline Oct-16 & $\begin{array}{l}\text {-CSRC and NDRC tigthened direct financing for real estate developers on bond issuance in } \\
\text { onshore and offshore markets. }\end{array}$ & $\sqrt{ }$ & & \\
\hline Nov-16 & $\begin{array}{l}\text { - PBC Shanghai tightened scrutiny on property-related lending. Banks enforced strictly on the } \\
\text { minimum down-payment ratio. About } 60 \text { percent of buyers had more than } 30 \text { percent down } \\
\text { payment in October. }\end{array}$ & & $\sqrt{ }$ & \\
\hline \multirow[t]{2}{*}{ Nov-16 } & - NDRC prohibited developers to issue enterprise bond for nonsocial housing projects. & $\sqrt{ }$ & & \\
\hline & Land supply & & & \\
\hline Jun-16 & -Tier 2 city Hefei planned to raise land supply and strengthen the land-bidding mechanism. & & & $\sqrt{ }$ \\
\hline Jul-16 & $\begin{array}{l}\text { Land and Development Bureau of Anhui province required land to be developped within two } \\
\text { years after sales. }\end{array}$ & & & $\sqrt{ }$ \\
\hline Aug-16 & $\begin{array}{l}\text {-Tier } 2 \text { city Suzhou tightened regulation on land-bidding and planned to increase land supply } \\
\text { over the next three years. }\end{array}$ & & & $\sqrt{ }$ \\
\hline Oct-16 & $\begin{array}{l}\text {-Developers were again required to increase supply of mid-sized apartments in Tier } 1 \text { cities. } \\
\text {-Several cities committed to raise land supply for residential use. } \\
\text {-Some cities required the reporting of sellling price for newly-constructed properties prior } \\
\text { granting sale permits, raised the land-bidding deposit requirement, and set price ceilings for } \\
\text {-Some tier } 2 \text { cities raised land-bidding deposit requirement and set price ceilings for land } \\
\text { auction. }\end{array}$ & & $\begin{array}{l}v \\
v\end{array}$ & $\begin{array}{l}v \\
v\end{array}$ \\
\hline
\end{tabular}




\begin{tabular}{|c|c|c|c|c|}
\hline \multicolumn{5}{|c|}{ Table 4. Results of the Panel Regression } \\
\hline \multicolumn{5}{|c|}{ Dependent variable: real residential house prices, change } \\
\hline & (1) & (2) & (3) & (4) \\
\hline Affordabilty, lagged & $-0.1419 * *$ & $-0.1568^{\star * \star}$ & $-0.1726^{* * *}$ & $-0.2117^{* \star *}$ \\
\hline Income per capita, change & 0.0225 & 0.0126 & 0.0225 & $0.1424^{* *}$ \\
\hline Working age population, change & 0.0228 & -0.0350 & -0.0231 & -0.0009 \\
\hline Bank credit, change & 0.0938 & $0.0905^{*}$ & $0.0900^{*}$ & 0.0476 \\
\hline Downpayment ratios, change, lagged & $-0.0709 *$ & -0.0431 & -0.0221 & -0.1313 \\
\hline interacted with Tier-1 dummy & & $-0.3528^{* \star *}$ & $-0.4680^{* * *}$ & $-0.4369 * * *$ \\
\hline interacted with Tier-2 dummy & & -0.0252 & -0.0283 & $-0.0503^{* *}$ \\
\hline Land supply per capita, change, lagged & -0.0023 & -0.0023 & $-0.0055^{*}$ & -0.0020 \\
\hline interacted with Tier-1 dummy & & & $0.0850^{* * *}$ & $0.0621^{\star *}$ \\
\hline Local mortgage rate, change & 0.0107 & $0.0121^{* *}$ & $0.0116^{* *}$ & -0.0029 \\
\hline Local government fiscal balance, change & -0.4279 & -0.3997 & -0.4450 & 0.0065 \\
\hline Stock prices, change & $0.0744^{\star * \star}$ & $0.0724^{\star \star \star}$ & $0.0706^{* * *}$ & \\
\hline RMB per USD, change & $-2.0645^{\star \star \star}$ & $-2.1142^{\star \star \star}$ & $-2.1473^{* * *}$ & \\
\hline Interbank interest rate, change & -0.0170 & $-0.0194^{*}$ & $-0.0230 * * *$ & \\
\hline Dummy for housing cycle & $-0.0661^{* * *}$ & $-0.0652^{* * *}$ & $-0.0635^{* * *}$ & \\
\hline Constant & -0.7315 & $-0.8016^{* \star *}$ & $-0.8748^{* * *}$ & $-1.0282^{* * *}$ \\
\hline \multicolumn{5}{|l|}{ Year } \\
\hline 2008 & & & & $-0.0701^{* * *}$ \\
\hline 2009 & & & & -0.0918 ** \\
\hline 2010 & & & & $-0.0897^{* * *}$ \\
\hline 2011 & & & & $-0.0916^{\star * \star}$ \\
\hline 2012 & & & & $-0.1548^{* * *}$ \\
\hline 2013 & & & & $-0.1071^{* * *}$ \\
\hline 2014 & & & & $-0.2207^{* * *}$ \\
\hline 2015 & & & & $-0.2289 * * *$ \\
\hline R-sq (overall) & 0.2974 & 0.3086 & 0.3026 & 0.3928 \\
\hline Number of obs & 418 & & & \\
\hline Number of groups & 68 & & & \\
\hline
\end{tabular}




\begin{tabular}{|c|c|c|c|c|c|c|c|}
\hline \multicolumn{8}{|c|}{ Table 5. Results of the Logit Regression } \\
\hline \multicolumn{5}{|c|}{ Dependent Variable: Dummy for Down Payment Ratio } & & (6) & (7) \\
\hline \multicolumn{8}{|c|}{ Loosening of the down payment requirement: $L T V_{i, t}=0$} \\
\hline$\overline{\text { Dhp }}$ & $\begin{array}{c}-14.657^{* * *} \\
(2.213)\end{array}$ & $\begin{array}{c}-18.283^{* * *} \\
(2.99)\end{array}$ & $\begin{array}{c}-17.540^{* \star *} \\
(4.324)\end{array}$ & $\begin{array}{c}-12.643^{* *} \\
(5.163)\end{array}$ & $\begin{array}{c}-14.499^{* * *} \\
(2.262)\end{array}$ & $\begin{array}{c}-27.348^{* * *} \\
(4.815)\end{array}$ & $\begin{array}{c}-16.104^{* * *} \\
(4.198)\end{array}$ \\
\hline $\mathrm{FT}^{*} \mathrm{Dhp}$ & & $\begin{array}{l}9.878^{\star \star} \\
(4.826)\end{array}$ & & & & & \\
\hline ST*Dhp & & $\begin{array}{c}4.889 \\
(4.278)\end{array}$ & & & & & \\
\hline inventory & & & $\begin{array}{l}0.800^{*} \\
(0.42)\end{array}$ & $\begin{array}{l}0.066 \\
(0.53)\end{array}$ & & & $\begin{array}{l}0.750^{*} \\
(0.41)\end{array}$ \\
\hline$F T^{*}$ inv & & & & $\begin{array}{c}15.213^{* *} \\
(6.27)\end{array}$ & & & \\
\hline ST*inv & & & & $\begin{array}{c}8.695^{* * *} \\
(2.06)\end{array}$ & & & \\
\hline DC1 & & & & & $\begin{array}{l}-1.323 \\
(1.20)\end{array}$ & $\begin{array}{l}2.072 \\
(2.97)\end{array}$ & $\begin{array}{l}-0.65 \\
(4.98)\end{array}$ \\
\hline DMR & & & & & & $\begin{array}{c}-1.335^{\star \star} \\
(0.61)\end{array}$ & \\
\hline stock & $\begin{array}{c}1.299^{\star * *} \\
(0.45)\end{array}$ & $\begin{array}{c}1.311^{\star \star \star} \\
(0.46)\end{array}$ & $\begin{array}{c}4.294^{\star \star \star} \\
(1.37)\end{array}$ & $\begin{array}{c}9.292^{\star \star \star} \\
(2.23)\end{array}$ & $\begin{array}{l}0.556 \\
(0.44)\end{array}$ & $\begin{array}{c}19.038^{\star \star \star} \\
(3.53)\end{array}$ & $\begin{array}{c}3.812^{* * *} \\
(1.29)\end{array}$ \\
\hline$f x$ & $14.874^{\star \star \star}$ & $14.535^{\star \star \star}$ & $45.643^{\star \star \star}$ & $60.771^{\star \star \star}$ & $13.145^{\star \star \star}$ & $-143.46^{\star \star \star}$ & $41.028^{\star \star \star}$ \\
\hline & $(2.73)$ & (2.75) & $(9.68)$ & $(13.25)$ & (2.78) & $(23.51)$ & $(9.54)$ \\
\hline interest & $\begin{array}{c}0.439^{* \star * *} \\
(0.10)\end{array}$ & $\begin{array}{c}0.404^{* * *} \\
(0.10)\end{array}$ & $\begin{array}{l}0.569^{*} \\
(0.32)\end{array}$ & $\begin{array}{c}0.7 \\
(0.45)\end{array}$ & $\begin{array}{c}0.248^{* *} \\
(0.10)\end{array}$ & $\begin{array}{c}1.106^{* *} \\
(0.45)\end{array}$ & $\begin{array}{l}0.441 \\
(0.34)\end{array}$ \\
\hline Staying un & hanged of th & e down pay & $\begin{array}{r}\text { ent require } \\
\text { (base o }\end{array}$ & $\begin{array}{l}\text { ent: } L T V_{i, t} \\
\text { tcome) }\end{array}$ & $=1$ & & \\
\hline Tightening & ff the down & bayment req & direment: $L 1$ & $V_{i, t}=2$ & & & \\
\hline Dhp & $\begin{array}{c}3.483^{\star *} \\
(1.76)\end{array}$ & $\begin{array}{l}0.766 \\
(2.36)\end{array}$ & $\begin{array}{l}-2.206 \\
(3.40)\end{array}$ & $\begin{array}{l}-1.296 \\
(4.22)\end{array}$ & $\begin{array}{c}6.036^{\star * \star} \\
(2.05)\end{array}$ & $\begin{array}{l}-4.349 \\
(4.77)\end{array}$ & $\begin{array}{l}0.485 \\
(3.49)\end{array}$ \\
\hline $\begin{array}{l}\mathrm{FT}{ }^{*} \mathrm{Dhp} \\
\mathrm{ST} \mathrm{T}^{*} \mathrm{Dhp}\end{array}$ & & $\begin{array}{l}1.817 \\
(4.57) \\
6.666^{\star} \\
(3.40)\end{array}$ & & & & & \\
\hline inventory & & & $\begin{array}{l}-0.242 \\
(0.39)\end{array}$ & $\begin{array}{l}-0.498 \\
(0.45)\end{array}$ & & & $\begin{array}{l}-0.519 \\
(0.50)\end{array}$ \\
\hline $\mathrm{FT} * \mathrm{inv}$ & & & & $\begin{array}{l}9.754^{*} \\
(5.80)\end{array}$ & & & \\
\hline ST*inv & & & & $\begin{array}{l}2.641^{*} \\
(1.39)\end{array}$ & & & \\
\hline DC1 & & & & & $\begin{array}{c}7.549^{\star \star \star} \\
(1.19)\end{array}$ & $\begin{array}{c}8.949^{\star \star \star} \\
(2.83)\end{array}$ & $\begin{array}{c}13.218^{\star \star *} \\
(4.18)\end{array}$ \\
\hline DMR & & & & & & $\begin{array}{c}2.487^{\star \star *} \\
(0.53)\end{array}$ & \\
\hline stock & $\begin{array}{c}4.301^{\star * *} \\
(0.44)\end{array}$ & $\begin{array}{c}4.432^{\star \star \star} \\
(0.45)\end{array}$ & $\begin{array}{c}2.682^{\star \star} \\
(1.28)\end{array}$ & $\begin{array}{c}5.820^{\star \star \star} \\
(1.98)\end{array}$ & $\begin{array}{c}4.765^{\star \star \star} \\
(0.53)\end{array}$ & $\begin{array}{c}20.941^{\star \star \star} \\
(3.71)\end{array}$ & $\begin{array}{c}2.596^{\star *} \\
(1.30)\end{array}$ \\
\hline$f x$ & $-16.901^{\star \star *}$ & $-18.109^{\star * *}$ & 6.981 & 14.808 & $-24.694^{* * *}$ & $-133.59^{\star \star \star *}$ & 7.252 \\
\hline & (3.46) & (3.59) & (8.47) & (11.12) & $(4.40)$ & (24.77) & (9.15) \\
\hline interest & $\begin{array}{l}0.117 \\
(0.08)\end{array}$ & $\begin{array}{l}0.091 \\
(0.08)\end{array}$ & $\begin{array}{l}0.223 \\
(0.20)\end{array}$ & $\begin{array}{l}0.172 \\
(0.23) \\
\end{array}$ & $\begin{array}{l}0.059 \\
(0.09)\end{array}$ & $\begin{array}{c}-0.685^{* * *} \\
(0.24) \\
\end{array}$ & $\begin{array}{c}0.661^{* *} \\
(0.26)\end{array}$ \\
\hline $\bar{N}$ & 840 & 840 & 169 & 169 & 763 & 476 & 168 \\
\hline Pseudo $R^{2}$ & 0.295 & 0.301 & 0.322 & 0.49 & 0.326 & 0.816 & 0.405 \\
\hline $\begin{array}{l}\text { Standard e } \\
{ }^{*} p<0.10 \text {, }\end{array}$ & $\begin{array}{l}\text { rs in paren } \\
<0.05,{ }^{* \star *}\end{array}$ & $\begin{array}{l}\text { eses } \\
0.01\end{array}$ & & & & & \\
\hline
\end{tabular}

CInternational Monetary Fund. Not for Redistribution 


\section{Annex 1. Residential Real Estate Data from National Bureau of Statistics and Local Housing Bureaus}

The National Bureau of Statistics published the Commodity Building Residential Selling Price index, which is based on aggregate sales value divided by the total floor space sold during a period. The index only consists of provincial level data without individual city information, and therefore tend to understate the increase in house prices. In addition, the NBS also released the price indices for 70 major cities for newly-constructed homes, which are most widely used in analyzing China's residential real estate markets. However, it tends to under-represent the smaller tier-3 and 4 cities. Similar limitations also exist for the aggregate inventory data (unsold floor space) (Chivakul and others 2015).

In light of these limitations, the note relies more on the data from local housing bureaus, which are more comprehensive and reflective on the underlying cyclical changes across citytiers. Local housing bureaus are local government divisions in charge of city-level real estate market under the Ministry of Housing and Urban-Rural Development. The bureaus execute administrative functions and are responsible for the registration of real estate sales, leases, mortgages, and transfers. As a result, their data tend to be more accurate based on actual transactions for purchases and sales of newly built residential units, while covering a more balanced sample with about 134 cities, grouped into four tiers based on the official definition ( 4 tier- 1 cities, 36 tier- 2 cities, and the rest are small tier- 3 and 4 cities). 


\section{References}

Andrews, D., 2010, "Real House Prices in OECD Countries: The Role of Demand Shocks and Structural and Policy Factors," OECD Economics Department Working Papers, No. 831.

Chivakul, M., W.R. Lam, X. Liu, W. Maliszewski, and A. Schipke "Understanding Residential Real Estate in China”, IMF Working Paper No.15/84.

Claessens, S., 2014, “An Overview of Macroprudential Policy Tools,” IMF Working Paper $14 / 214$.

Deutsche Bank, 2016, "Analyzing the Property Exposure."

Fang, H., Gu, Q., Xiong, W., and L. Zhou, 2015, "Demystifying the Chinese Housing Boom," NBER Working Paper No. 21112.

Flood, K and S. Morin, 2008, "House Prices and Consumer Spending," Bank of Canada Review, Summer 2008.

Glaeser, E., W. Huang, Y. Ma, and A. Shleifer, 2016, “A Real Estate Boom with Chinese Characteristics", NBER Working Paper No. 22789.

He, D., Nier, E. and H. Kang, 2016, "Macroprudential measures for addressing housing sector risks," BIS Paper No. 86.

Huang, X., T. Jin, and J. Zhang, 2016, "Monetary Policy, Hot Money and Housing Price Growth across Chinese Cities," Harvard University OpenScholar Working Paper.

Huang, Z., C. Wu, and X. Du, 2008, "Real Estate Investment and Economic Growth: An Analysis of National and Regional Panel Data," Finance \& Trade Economics, Vol. 8.

Igan D. and P. Loungani, 2012, “Global Housing Cycle,” IMF Working Paper 12/217.

IMF, 2008, "The Changing Housing Cycle and the Implications for Monetary Policy," World Economic Outlook, Chapter 3, October 2008.

,2014, "Staff Guidance Note on Macroprudential Policy_Detailed Guidance on Instruments".

,2015, “People's Republic of China: 2017 Article IV Consultation Staff Report”, IMF Country Report No. 15/234.

, 2017, "People's Republic of China: 2017 Article IV Consultation Staff Report”, IMF Country Report No. 17/247.

Shi, Y., 2017, "Real Estate Booms and Endogenous Productivity Growth”, manuscript.

Jacome, L. and S. Mitra, 2015, "LTV and DTI: Going Granular,” IMF Working Paper 
$15 / 154$

Vitek, F., 2015, "Macrofinancial Analysis in the World Economy: A Panel Dynamic Stochastic General Equilibrium Approach,” IMF Working Paper 15/227.

Wang, B. and T. Sun, 2013, "How Effective Are Macroprudential Policies in China?" IMF Working Paper 13/75.

Wright K., T. Wang, D. Kwok, E. Lee, and E. Cheung, 2016, “UBS Evidence Lab: China Housing Survey-Borrowing from the Future", UBS Evidence Lab series.

Wu, J., J. Gyourko, Y.H. Deng, 2016, "Evaluating the Risk of Chinese Housing Markets: What we know and what we need to know?" NBER Working Paper No. 21346. 